\title{
Effect of adsorbent and enzyme preparations on productivity of fattening steers with diets containing heavy metals
}

\author{
S.R. Hamikoeva ${ }^{1}$, R.B. Temiraev ${ }^{1 \& 2^{*}}$, M.G. Chabaev $^{3}$, E.Yu. Tsis ${ }^{3}$, V.S. \\ Gappoeva $^{4}$, Z.G. Khabaeva ${ }^{4}$, A.R. Gagloeva ${ }^{4}$
}

${ }^{1}$ Gorsky State Agrarian University, 362040, Vladikavkaz, 37 Kirov Street; ${ }^{2}$ North-Caucasian Mining and Metallurgical Institute (State Technological University), Vladikavkaz, 362021; ${ }^{3}$ Federal Science Center for Animal Husbandry named after Academy Member L.K. Ernst 142132,Moscow region, Podolsk City district, Dubrovitsy settlement, house 60; ${ }^{4}$ North-Ossetian State University named after K.L. Khetagurov, Vladikavkaz, 362025, Russian Federation.

*Corresponding author email: temiraev@mail.ru

Journal of Livestock Science (ISSN online 2277-6214) 12: 60-64

Received on 9/9/20; Accepted on 19/12/2020; Published on 7/1/2021

doi. 10.33259/JLivestSci.2021.60-64

\begin{abstract}
The territory of the Republic of North Ossetia - Alania is one of the most heavy metal contaminated regions in the Russian Federation, due to the number of large non-ferrous metallurgy enterprises in Vladikavkaz. The research is aimed at studying the effect of enzyme preparation Celloviridin G20x and adsorbent Toxfin supplements in the fattening steers' diets containing an increased heavy metal level on their bio-productive indicators. During the experiment, 40 six month-old Simmental steers were selected, which by the analogue scale were divided into 4 groups of 10 heads each. The experiment lasted 12 months. The resulting digital material was processed statistically using the Excel information program. The research results showed that the best productive and physiological effect was obtained when joint feeding these feed additives. Thus, when joint feeding preparations Celloviridin G20x at a dose of $70 \mathrm{~g} / \mathrm{t}$ and Toxfin at a dose of $1 \mathrm{~kg} / \mathrm{t}$ mixed feed, the third test group had a significant increase in the average daily live weight gain and the energy and digestible protein to product conversion. When joint feeding these preparations as part of the diet with an increased content of zinc, lead and cadmium, there was an increase in the breakdown of feeds protein, cellulose and easily soluble carbohydrates. Due to this, the animals of the third test group significantly $(\mathrm{P}<0.05)$ exceeded their control counterparts in the digestibility coefficients of dry matter, organic matter, crude protein, crude fiber, and nitrogen free extractives. In the process of heavy metal detox by joint feeding preparations Celloviridin G20x and Toxfin the counterparts in the third test group vs. the control for a day deposited more nitrogen in the body.
\end{abstract}

Keywords: bulls; heavy metals; dietary supplements; detoxification; gain; digestibility. 


\section{Introduction}

It is known that the physical and chemical properties of young cattle meat are significantly affected by chemical toxicants. Among them, heavy metal salts have a special place. They have a high biological activity and accumulating in the body, negatively affect the metabolism. The toxic effect of these toxicants is due to the fact that they inactivate a number of vital enzymes (Temiraev et al., 2015; Dzodzieva et al., 2015; Tsalieva et al., 2017; Temiraev et al., 2017; Yuldashbaev et al., 2020).

The territory of the RNO - Alania belongs to the most heavy metal contaminated regions in Russia due to the high concentration of non-ferrous metallurgy enterprises in the city of Vladikavkaz, such as JSC «Electrozinc», JSC «Pobedit», etc. Along with, the steers' feeding conditions affect the development and ratio of plastic material in their body, the yield and quality of meat (Temiraev et al., 2011; Biswas et al., 2010; Temiraev et al., 2012; Kokaeva et al., 2017; Temiraev et al., 2020). High detoxification effect is reported when introducing adsorbents in combination with biologically active additives (vitamins, antioxidants and enzyme preparations) into the fattening steers' diets, which contributes to improve the beef nutritional value and environmental safety (Temiraev et al., 2012; Tedtova et al., 2017; Yarmots et al., 2013; Vityuk et al., 2017; Kokaeva et al., 2020).

The present research is aimed at studying the effect of enzyme preparation Celloviridin G20x and adsorbent Toxfin supplements in the fattening steers' diets containing an increased heavy metal level on their bio-productive indicators (Khamikoeva et al., 2018).

\section{Material and methods}

The scientific experimentation according to the scheme shown in table 1 and conducted in the conditions of the agricultural production cooperative «Vesna» in the Republic of North Ossetia-Alania was focused on implementation of specified research tasks. For this purpose, 40 six month-old Simmental steers were selected, which by the analogue scale were divided into 4 groups of 10 heads each. The experiment lasted 12 months.

The dynamics of the steers' live weight was monitored based on the results of monthly control weighing. According to their data, the absolute and average daily body weight gain of test steers was calculated.

Celloviridin G20X. Manufacturer. Berdsk plant of biological preparations, Russia. Composition and form of release. The preparation is obtained by drying in a spray dryer the filtrate obtained by submerged cultivation of the fungus Trichoderma reesei (viride). Fine, hygroscopic, amorphous powder from light yellow to dark brown, containing a complex of enzymes capable of hydrolyzing plant polysaccharides - cellulases, glucanases, xylanases, hemicellulases and others.

Toxfin is a new generation adsorbent manufactured by Kemin Europa N.V. (Belgium). It is a dry powder of beige-greenish color, intended for the adsorption of mycotoxins in grain and mixed fodder for farm animals and poultry. Toxfin contains in its composition: binders hydroaluminosilicate - bentonite within 48.9-50.9\%, sepiolite within $39.0-41.0 \%$, steatites - up to $0.2-0.6 \%$, silicon oxide - up to $0.3-0.7 \%$; preservatives - calcium propionate up to $4.0-5.0 \%$, sorbic acid - up to $0.05-0.15 \%$, fumaric acid - up to $0.2-0.4 \%$; antioxidant - butylhydroxyanisole up to $0.05-0.15 \%$ and the carrier - table salt - up to 3.7-4.7\%. The sorption capacity of this drug is at least $95 \%$. The diet of the test animals is shown in table 2.

According to the chemical analysis results, it was found that the diets of the test animals exceeded the maximum permissible concentration for zinc: at the age of 6-9 months - 2.01 times; 9-12 months - 2.14 times; 12 15 months -2.17 times and $15-18$ months -2.21 times. During these age periods, the diets of the test steers were found to contain lead in the amount of $160.5 ; 180.1 ; 196.9$ and $204.1 \mathrm{mg}$ and cadmium $-10.31 ; 10.42 ; 11.04$ and $12.20 \mathrm{mg}$, respectively. The enzyme preparation and adsorbent were added to the mixed feed using industrial dispensers by three-stage mixing.

The physiological exchange experiment was carried out according to the generally accepted method (Ovsyannikov) using animals of two groups: control and the third test (the best productive) groups. To do this, three heads were selected from each group, which were housed tethered in individual stalls with the sloping floor covered with the rubber mat. During 7 days, three times a day, $100 \mathrm{~g}$ of each head's feces and urine were collected, weighed, and taken average samples. Based on the results of the chemical analysis of feed, feces and urine samples, the digestibility and accessibility of diet nutrients were calculated.

The content of heavy metals in the feed samples was determined by the atomic adsorption method on an AAZ-115-M1 spectrophotometer in the laboratory of aeroecology of the Gorsky State Agrarian University (Russia). The resulting data was processed statistically using by Student's criterion in the the Excel information program

Table 1 - Scheme of scientific experimentation $(n=10)$

\begin{tabular}{|l|c|c|c|}
\hline \multirow{2}{*}{ Group } & $\begin{array}{c}\text { Basic diet (BD) } \\
\text { with a high content } \\
\text { of } \mathrm{Zn}, \mathrm{Pb} \text { and Cd }\end{array}$ & $\begin{array}{c}\text { Celloviridin G20x, } \\
\text { g/t mixed feed }\end{array}$ & $\begin{array}{c}\text { Toxfin, } \\
\text { g/t mixed feed }\end{array}$ \\
\hline control & BD & - & - \\
\hline 1 test & BD & 70 & - \\
\hline 2 test & BD & - & 1,0 \\
\hline 3 test & BD & 70 & 1.0 \\
\hline
\end{tabular}


Table 2 - Daily diet for steers aged 9-12 months

\begin{tabular}{|l|l|l|}
\hline Indicator & Required rate & Indeed contains \\
\hline Feed $(\mathrm{kg})$ and additives: & & \\
\hline Sudan grass hay & - & 2 \\
\hline Corn silage + sorghum & - & 10 \\
\hline Dry pulp & - & 0.9 \\
\hline Mixed feed & - & 2.85 \\
\hline Feed molasses & - & 0.8 \\
\hline Table salt, g & 35 & 28 \\
\hline The diet contains: & & \\
\hline EFU & 5.30 & 5.33 \\
\hline Dry matter, kg & 70.0 & 69.8 \\
\hline Exchange energy, MJ & 53.0 & 53.30 \\
\hline Crude protein, g & 1175 & 1200 \\
\hline Digestible protein, g & 765 & 778.7 \\
\hline Crude fiber, g & 1990 & 2008 \\
\hline Starch, g & 1215 & 1202 \\
\hline Sugar, g & 810 & 806 \\
\hline Crude fat, g & 310 & 298 \\
\hline Calcium, g & 54 & 56,1 \\
\hline Phosphorus, g & 29 & 30 \\
\hline Magnesium, g & 20 & 19.8 \\
\hline Potassium, g & 69 & 67.8 \\
\hline Sulfur, g & 27 & 26.5 \\
\hline Iron, mg & 600 & 1804 \\
\hline Copper, mg & 85 & 83 \\
\hline Zinc, mg & 450 & 855.48 \\
\hline Lead, mg & - & 264 \\
\hline Cadmium, mg & - & 18.18 \\
\hline Cobalt, mg & 6 & 5.93 \\
\hline Manganese, mg & 400 & 397 \\
\hline Iodine, mg & 3 & 3.03 \\
\hline Carotene, mg & 210 & 231 \\
\hline Vitamin D, thou. IU & 4.3 & 4.5 \\
\hline Vitamin E, mg & 330 & 341 \\
\hline & & \\
\hline
\end{tabular}

\section{Results and discussion}

The excessive content of heavy metal salts in the diet affects the young animals' growth rate and feed conversion. Therefore, according to the results of the control weighing, the growth rate, energy consumption and digestible protein per $1 \mathrm{~kg}$ of steers' gain in the compared groups were determined (table 3 ).

It was found that at the age of 18 months, the highest growth energy characterized animals in the third test group, which relative to the control had a significantly $(\mathrm{P}<0.05) 6.03 \%$ greater final live weight, so that the steers of this group vs. the control were characterized by higher absolute and average daily gain by $10.05 \%(\mathrm{P}<0.05)$. Along with this, the best feed-conversion efficiency characterized animals in the third test group, which per $1 \mathrm{~kg}$ gain consumed vs. the control $9.42 \%$ of EFU and $9.09 \%$ less of digestible protein. Our data are consistent with the data obtained by a number of authors (Dzodzieva et al., 2015; Kokaeva et al., 2017).

At the age of 15 months, the exchange experiment was conducted using animals of the control and best productive third test groups, for which purpose three heads were selected from each group. According to the results of the chemical analysis of feeds and their residues, the nutrient digestibility coefficients of test animals' diets were calculated (table 4).

Analysis of the data from the exchange experiment shows that there were no significant $(\mathrm{P}>0.05)$ differences in the level of crude fat digestibility between steers of the control and the third test groups.

At the same time, when joint feeding the enzyme preparation Celloviridin G20x and adsorbent Toxfin as part of diets with the increased content of zinc, lead and cadmium, there was an increase in the breakdown of feeds protein, cellulose and easily soluble carbohydrates (nitrogen-free extractives). Due to this, the animals of the third test group significantly $(\mathrm{P}<0.05)$ exceeded their control counterparts in the digestibility coefficients of dry matter by $2.90 \%$, organic matter - by $3.11 \%$, crude protein - by $2.89 \%$, crude cellulose - by $2.31 \%$ and nitrogen-free extractives - by $3,88 \%$, respectively.

This indicates that using the test feed additives activated in animals of the third test group proteolytic, 
cellulolytic and amylolytic enzymes in their rumen microflora, that is, improving the digestibility of dry and organic matter during heavy metal detox indicates with the help of these adsorbents the optimization of digestive metabolic processes in test young animals by activating the fermentolysis of feeds protein, cellulose and starchy substances. Our data are consistent with the data obtained by a number of authors (Kokaeva et al., 2017; Yuldashbaev et al., 2020).

It is known that increasing digestibility of the diet protein does not always simultaneously increase its accessibility, as various toxicants in feeds may activate the deamination process, which increases the amount of nitrogen excreted with animals' urine. Table 5 shows the nitrogen balance in test animals.

Table 3 - Productivity and nutrients consumption per $1 \mathrm{~kg}$ of test animals' gain $(\mathrm{n}=10)$

\begin{tabular}{|l|l|l|l|l|}
\hline \multirow{2}{*}{\multicolumn{1}{|c|}{ Indicator }} & \multicolumn{4}{c|}{ Groups } \\
\cline { 2 - 5 } & \multicolumn{1}{|c|}{ control } & \multicolumn{1}{c|}{1 test } & \multicolumn{1}{c|}{3 test } \\
\hline Live weight, kg: & & & $169.5 \pm 0.39$ & $169.7 \pm 0.42$ \\
\hline $\begin{array}{l}\text { at the beginning of the } \\
\text { experiment }\end{array}$ & $169.6 \pm 0.38$ & $169.8 \pm 0.38$ & & \\
\hline at the end of the experiment & $422.3 \pm 3.11$ & $436.7 \pm 2.98$ & $437.1 \pm 3.33$ & $447.8 \pm 3.16$ \\
\hline Live weight gain: & & & & \\
\hline absolute, kg & $252.7 \pm 3.05$ & $266.9 \pm 2.85$ & $267.6 \pm 3.16$ & $278.1 \pm 3.10$ \\
\hline average daily, g & $692.33 \pm 14.4$ & $731.23 \pm 15.0$ & $733.15 \pm 14.2$ & $761.92 \pm 16.0$ \\
\hline In \% to control & 100.00 & 105.62 & 105.90 & 110,05 \\
\hline Consumed per 1kg live weight gain, kg: & 7.96 & 7.53 & 7.50 & 7.21 \\
\hline EFU & 740.66 & 700.72 & 699.40 & 673.33 \\
\hline digestible protein, g & & & \\
\hline
\end{tabular}

Table 4 - Nutrients digestibility coefficients of diets, $\% \quad(n=3)$

\begin{tabular}{|l|c|c|}
\hline \multirow{2}{*}{\multicolumn{1}{|c|}{ Indicator }} & \multicolumn{2}{c|}{ Group } \\
\cline { 2 - 3 } & \multicolumn{1}{c|}{ control } & 3 test \\
\hline Dry matter & $68.41 \pm 0.37$ & $71.31 \pm 0.42$ \\
\hline Organic matter & $69.30 \pm 0.44$ & $72.41 \pm 0.37$ \\
\hline Crude protein & $65.60 \pm 0.39$ & $68.49 \pm 0.36$ \\
\hline Crude fat & $60.59 \pm 0.41$ & $60.00 \pm 0.47$ \\
\hline Crude cellulose & $58.50 \pm 0.68$ & $60.81 \pm 0.45$ \\
\hline Nitrogen-free extractives & $76.01 \pm 0.48$ & $79.89 \pm 0.50$ \\
\hline
\end{tabular}

Table 5 - Use of the diet nitrogen by test steers, $\mathrm{g}(\mathrm{n}=3)$

\begin{tabular}{|c|c|c|}
\hline \multirow[b]{2}{*}{ Indicator } & \multicolumn{2}{|c|}{ Group } \\
\hline & control & 3 test \\
\hline Consumed nitrogen & $159.17 \pm 0.48$ & $159.26 \pm 0.50$ \\
\hline Excreted nitrogen in feces & $55.98 \pm 0.45$ & $50.44 \pm 0.40$ \\
\hline Excreted nitrogen in urine & $72.94 \pm 0.41$ & $74.18 \pm 0.31$ \\
\hline Deposited in the body & $30.25 \pm 0.26$ & $34.64 \pm 0.36$ \\
\hline $\begin{array}{l}\text { Used nitrogen, \%: } \\
\text { of consumed }\end{array}$ & $19.01 \pm 0.29$ & $21.75 \pm 0.34$ \\
\hline of digested & $29.31 \pm 0.38$ & $31.83 \pm 0.47$ \\
\hline
\end{tabular}

It was found that the nitrogen balance in the steers of the control and third test groups was positive in all cases. However, in the process of heavy metal detox by joint feeding the enzyme preparation Celloviridin G20x and adsorbent Toxfin, the counterparts of the third test group vs. the control for a day deposited $4.39 \mathrm{~g}(\mathrm{P}<0.05)$ more nitrogen in the body. The data obtained show that the level of feed nitrogen use corresponded to the average daily body weight gain of the test fattening young cattle. Our data are consistent with the data obtained by a number of authors (Dzodzieva et al., 2015; Vityuk et al., 2017)

In the process of heavy metal detox, the body of steers in the third test group showed compared to the control, a significant $(\mathrm{P}<0.05)$ increase in the level of nitrogen use of the consumed with feed amount by $2.74 \%$ and of the digested amount - by $2.52 \%$.

Conclusion. To increase the digestibility and use of nutrients in feeds with increased heavy metal level, the enzyme preparation Celloviridin G20x at a dose of $70 \mathrm{~g} / \mathrm{t}$ and adsorbent Toxfin at a dose of $1 \mathrm{~kg} / \mathrm{t}$ mixed feed should be jointly included in the diets of fattening young cattle. 


\section{References}

1). Biswas A., Mohan J., Sastry K.V.H. 2010. Effect of vitamin E on production performance and egg quality traits in Indian native Kadaknath hen. Asian-Australasian Journal of Animal Science 23: 9-12.

2). Dzodzieva E.S., Kokaeva M.G., Temiraev R.B., Abramova G.A., Gurtsieva D.O. 2015. Comparative assessment of the quality of bulls meat fattening in the technogenic zone. Meat industry - Moscow. 2: 46-49.

3). Khamikoeva, S.R. Tedtova V.V., Dzodzieva E.S., Khamitsaeva Z.S., Dzagurov B.A., Kesaev H.E., Godzhiev R.S. 2018. Influence of preparations toxfin and celloviridin g20x on productivity and indices of digestion of fattening gobies in the technogenic zone. Bulletin of the Mountain State Agrarian University, Vladikavkaz. 55(4.): 120-125.

4). Kokaeva M.G., Temiraev R.B., Beslaneev E.V., Cherchesova S.K., Kubatieva (Gutieva) Z.A. and Kozyrev S.G. 2017. Influence of antioxidant and adsorbent on the processes of digestive and intermediate metabolism in lacting cows during denitrification. Journal of Pharmaceutical Sciences and Research 9 (12): 2401-2404.

5). Kokaeva M.G., Temiraev R.B., Dzhaboeva A.S., Osikina R.V., Gazzaeva M.S., Shugusheva L.H., Sattsaeva I.K., Nerovnykh L.P., Arutyunova G.Y., Efendiev B.S. 2020. Method for increasing the ecological and food values of milk and dairy products. Journal of Livestock Science (ISSN online 2277-6214) 11: 14-19.

6). Tedtova V.V., Kozhokov M.K., Shugusheva L.H., Kanukova V.N., Baeva A.A., Vityuk L.A. 2017. Preventive and detoxicative action of probiotics on metabolism and consumer quality of broilers meat. Journal of Pharmaceutical Sciences and Research. 9 (6): 997-1001.

7). Temiraev R.B., Kokaeva F.F., Tedtova V.V., Baeva A.A., Khadikova M.A., Abaev A.V. 2011. Method for improving the dietary meat quality and broiler chickens' metabolism in the conditions of the technogenic zone of RNO - Alania. Proceedings of Gorsky State Agrarian University, Vladikavkaz. 49. (4): 130-133.

8). Temiraev R.B., Vityuk L.A., Kokaeva M.G., Dzhibilova N.S., Kanukov A.M. 2012. Method for improving the consumer qualities of Ossetian cheese. Proceedings of Gorsky State Agrarian University, Vladikavkaz 49(3): 169-173.

9). Temiraev R.B., Vityuk L.A., Ktsoyeva I.I., Karsanov M.D. 2015. Indices of natural resistance and peroxidation of lipids in poultry fed biologically active supplements withrations. Livestock of the South of Russia Krasnodar. 3-5: 25-30.

10). Temiraev R.B., Tsalieva L.V., Balikoeva F.R., Plieva I.G. 2012. Features of young pigs' metabolism when using autolysate of beer and wine yeasts and enzyme preparations. Proceedings of Gorsky State Agrarian University Vladikavkaz 49(1-2): 109-112.

11). Temiraev V.H., Baeva A.A., Vityuk L.A., Mamukaev M.N., Yurina N.A., Ktsoeva I.I., Bobyleva L.A., Zagaraeva E.F., Kokov T.N., Vologirova F.A. 2020. Effect of probiotics on digestive metabolism in growing and laying poultry birds. Journal of Livestock Science 11: 33-39.

12). Temiraev V.K., Kairov V.R., Temiraev R.B., Kubatieva Z.A. and Gukezhev V.M. 2017. Method to improve productive performance and digestion exchange of broiler chickens with reduced risk of aflatoxicosis. Ecology, Environment and Conservation. 23 (1): 554-561.

13). Tsalieva L.V., Temiraev R.B., Kononenko S.I., Dzagurov B.A., Gazzaeva M.S. and Grevtsova S.A. 2017. Ecological and consumer properties of pig meat from different breeds produced in technogenic zone. Journal of Pharmaceutical Sciences and Research. 9 (12): 2397-2400.

14). Vityuk L.A., Baeva A.A., Kochieva I.V., Stolbovskaya A.A., Kononenko S.I., Yarmoc A.V., Tletseruk I.R., Bobyleva L.A., Tsugkiev B.G., Sattsaeva I.K. 2017. Assessment of the productivity of broiler chicken sunder and the heavy metal detoxication in the context of industrial pollution. Pollution Research. 36 (4): 748-754.

15). Yarmots A.V. Temiraev R.B., Vityuk L.A., Kokaeva M.G., Plieva Z.K. 2013. Method for improving the ecological and nutritional quality of milk and dairy products. New technologies Maykop 3: 128-134.

16). Yuldashbaev Y.A., Temiraev R.B., Tedtova V.V., Temiraev K.B., Osikina R.V., Gazzaeva M.S., Shugusheva L.H., Sattsaeva I.K., Udychak M.M. 2020. Control of physical and chemical qualities of milk and dairy food products obtained in an ecologically unfavorable zone. Journal of Livestock Science 11: 8-13. 